\title{
HOMERO E XENOFONTE: PANTEIA, ABRADATAS E A GUERRA DE CIRO'
}

\author{
Lucia Sano* * Professora de Língua \\ e Literatura Grega, \\ Universidade Federal \\ Recebido em: 25/03/2019 \\ de São Paulo. \\ Aprovado em: 16/04/2019 \\ lucia.sano@unifesp.br
}

RESUMO: A intenção do artigo é discutir a representação da morte dos personagens Panteia e Abradatas na Ciropédia de Xenofonte, considerando-se o contexto mais amplo de como o tema da guerra é apresentado na obra. Sugere-se que a identificação de Panteia e Abradatas com Andrômaca e Heitor serve ao propósito de introduzir o questionamento da própria representação positiva da guerra na narrativa de Xenofonte, bem como a da conduta de seu herói, que por meio do conflito violento ascende à posição de líder do maior império até então conhecido.

PALAVRAS-CHAVE: Xenofonte; Ciropédia; Iliada; recepção dos clássicos; guerra.

ABSTRACT: This paper analyzes the death of the characters Panthea and Abradatas in Xenophon's Cyropaedia, within the broader context of how the theme of war is presented in the work. We suggest that the identification of Panthea and Abradatas with Andromache and Hektor aims to introduce the questioning of the positive representation of war in Xenophon's narrative, as well as of the conduct of its hero - who ascends to the position of leader of the greatest empire hitherto known through violent conflict.

KEYWORDS: Xenophon; Cyropaedia; Iliad; classical reception; war.

\footnotetext{
${ }^{1}$ Gostaria de agradecer aos colegas que participaram do colóquio "A Ilíada de Homero e sua recepção na Antiguidade e Modernidade”, realizado na Universidade de São Paulo em setembro de 2018, e que muito contribuíram para o aprimoramento da discussão apresentada neste artigo.
} 


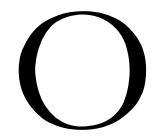
leitor que se interessar sobre como Homero é citado ou usado como modelo por Xenofonte em sua obra talvez se admire com quão menos do que se poderia esperar o poeta é mencionado pelo autor. Yamagata (2012) lista, nas consideradas opera maiora, apenas 26 menções explícitas à Ilíada ou à Odisseia, que aparecem principalmente nas obras socráticas (11 vezes nos Memoráveis, 11 vezes no Banquete). Esse pouco, no entanto, é de grande relevância para se entender como os dois poemas eram lidos na época em que Xenofonte escreveu: no Banquete (III.6), por exemplo, temos possivelmente o primeiro registro da concepção de que os poemas homéricos possuem byponoiai ("sentidos subjacentes"), ${ }^{2}$ dos quais os rapsodos não se apercebem, sendo, portanto, "os mais estúpidos dos homens", 3 a despeito de conhecerem os poemas de cor. A disputa pela correta interpretação dos poemas (e seu uso político), por sua vez, é demonstrada nos Memoráveis (I.2.58-9), quando se esclarece que Sócrates nunca interpretou a passagem em que Odisseu, no canto II da Ilíada, trata de forma dura o demos, pouco antes da célebre intervenção de Tersites, como um louvor do poeta à sova dos homens pobres e do povo. Ele teria defendido, na verdade, que aqueles que não são úteis à cidade, ao exército e ao povo devem ser tolhidos, ainda que sejam ricos.

Ao mesmo tempo, apesar das poucas menções explícitas, também se pode considerar que Homero está em toda parte na obra de Xenofonte. Ele está presente, por exemplo, no tema predileto do ateniense, o da boa liderança, quando é possível remontar algumas das características básicas que definem um bom líder aos heróis homéricos, que conjugam bravura e astúcia. ${ }^{4}$ Xenofonte também aproxima Sócrates de Odisseu, chamando o filósofo de um

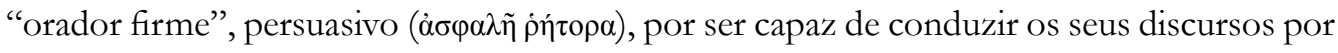
meio das opiniões dos seus interlocutores (IV.6.15).

Porém, nas narrativas longas de Xenofonte, de fato é raro encontrar passagens em que se pode afirmar com resolução que o autor está usando Homero como seu modelo narrativo. Mesmo a figura de Odisseu como um ideal de narrador historiográfico, ${ }^{5}$ um quase lugar-comum entre os historiadores gregos, é um aspecto que se observa sobretudo na Anábase, em que o quadro geral do deslocamento de um exército que busca retornar à Grécia passando por povos hostis cria um paralelo imediato com a Odisseia. ${ }^{6}$ Se Heródoto

\footnotetext{
${ }^{2}$ Cf. Platão, Rep. 2.378d6 e Nünlist (2014, p.737, n. 104).

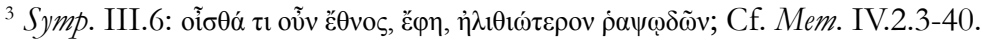

${ }^{4}$ Várias das características que desde Homero são vistas como positivas num líder são aceitas também por Xenofonte, como observa Marincola (2017, p. 110): “Homeric models of leadership are never far from Xenophon's thoughts, and just as leaders are expected to be brave fighters, they are also expected to have some of Odysseus' resourcefulness and cunning, and to use guile and ruses when those will accomplish more than force”. A análise mais detalhada da questão é feita por Gray (2011, p.120ss). ${ }^{5}$ Cf. Marincola (2007).

${ }^{6}$ Há duas referências claras à Odisseia na Anábase: Xenofonte alerta o exército para não se esquecer de casa, permanecendo com as belas mulheres nativas, como os companheiros de Odisseu teriam feito junto aos lotófagos. No livro V, Leon afirma que deseja pôr fim às suas penas e retornar à Grécia deitado numa doca como Odisseu. Para outras passagens, cf. Tuplin (2003); Howland (2000); Lossau (1990).
} 
é o historiador homerikotatos, veja-se, à guisa de exemplo fácil, como a leitura detalhada que Tuplin (2003), um leitor muito mais perspicaz do que eu da obra xenofôntica, faz das alusões à épica homérica na Anábase é salpicada por hesitação e dúvida, expressas das seguintes formas: "perhaps there is an allusion...", "it is very hard to tell...", "is there a literary allusion here?" etc. Considerando contexto e uso de vocabulário, cuja incidência considera "longe de dar à narrativa um tom homérico consistente", porém, ele conclui que Xenofonte muito provavelmente tinha Homero em mente em algumas passagens - mas essa é uma conclusão a que se chega não sem esforço. Com um pouco mais de clareza, podemos notar que há passagens na obra xenofôntica em que a excelência de um comandante militar é descrita de forma a emular uma aristeia típica de um herói iliádico, como é o caso do relato da vitória de Ciro sobre Creso na Ciropédia, algo demonstrado por Howie (1996).

Neste artigo, decidi voltar-me às passagens na obra narrativa de Xenofonte que os leitores e comentadores mais frequentemente associam a Homero. Para além da cena de despedida em que os protagonistas são Panteia e Abradatas na Ciropédia, discutirei também as subsequentes mortes dos personagens, considerando-as dentro do contexto mais amplo de como o tema da guerra é representado com alguns tons homéricos nessa obra de Xenofonte. Eu pretendo argumentar que Panteia e Abradatas são aproximados de Heitor e Andrômaca porque, na sequência da narrativa, a representação de suas mortes trará para a Ciropédia o questionamento da validade da guerra e da conduta de Ciro, em um tratamento crítico dos valores representados na obra semelhante ao que vemos na Iliada. Afinal, é por meio da guerra que Ciro ergue seu império e é como general que, ao longo da maior parte da narrativa, conhecemos o seu caráter.

\section{A guerra de Ciro}

Xenofonte dá início à Ciropédia declarando que nenhum outro animal é, por natureza, mais difícil de governar do que o homem - fato que faz de Ciro da Pérsia, o Grande (c. 590530 a.C.), conquistador e governante do maior império até então visto, um líder excepcional (I.1.3). Por esse motivo, ele decide relatar tudo aquilo que pôde aprender e entender sobre ele (I.1.6). Eu sou adepta de uma leitura não-irônica, não-straussiana da obra, ${ }^{7}$ e considero que a narrativa se desenvolve em episódios encomiásticos, cuja função é demonstrar a superioridade de Ciro como líder, ainda que em alguns momentos Xenofonte abra espaço também a uma perspectiva crítica da atuação do persa.

A guerra surge logo no início da Ciropédia, já que a educação das crianças e dos jovens na Pérsia tem como um dos seus principais objetivos a preparação para o confronto bélico. $\mathrm{Na}$ Média, aonde Ciro chega menino, em determinado ponto ele começa a participar de duas atividades que marcam seu processo de amadurecimento: primeiro, ele é autorizado a sair para $\operatorname{caçar}^{8}$ e, logo depois, participa do seu primeiro conflito militar, quando ainda é um

\footnotetext{
${ }^{7}$ Gray (2011) e Danzig (2012) são boas análises não irônicas recentes.

${ }^{8}$ Xenofonte ressalta diversas vezes ao longo da Ciropédia que a caça é uma atividade preparatória para a guerra.
} 
adolescente de quinze ou dezesseis anos. A Ciro, nesse momento, já parecia que ele "nunca" viria a vestir as armas, tão grande era seu desejo de utilizá-las (I.4.18). Essa primeiríssima atuação de Ciro num conflito militar rende-lhe kleos ("glória") imediato: por causa dele, ele

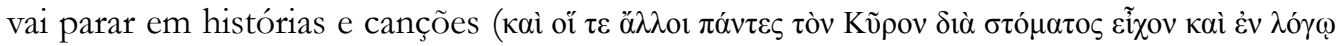

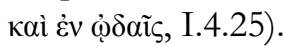

Há, nesse momento da narrativa, uma passagem que sempre me pareceu ao mesmo tempo impactante e sutil no que diz respeito à formação de Ciro: o narrador relata sua fascinação com os cadáveres dos inimigos na primeira batalha de que toma parte. ${ }^{9} \mathrm{~A}$ forma como a cena é narrada chama a atenção para o fato de que seu avô Astíages pensava perceber melhor do que o jovem Ciro a disposição dos soldados, mas é obrigado a dar-lhe razão assim que o neto expõe sua visão do posicionamento dos inimigos. A atuação de Ciro na sequência é decisiva em outros aspectos, mas o narrador não deixa de observar que ele

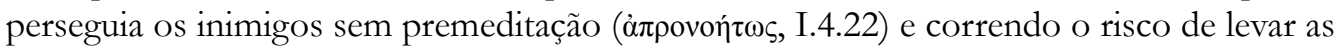
suas tropas a cair em desordem.

O trecho seguinte é narrado logo após a vitória dos medos (I.4.24): ${ }^{10}$

Depois disso, Astíages iniciou a retirada, muito satisfeito pelo sucesso da cavalaria, mas sem saber o que deveria dizer a Ciro, pois, mesmo que entendesse que era ele o responsável por tal feito, por outro lado, percebia que sua ousadia o deixara enlouquecido. E ainda, enquanto os outros estavam tomando o caminho de casa, Ciro, sozinho, não fazia outra coisa a não ser observar os mortos, cavalgando ao redor deles; foi com dificuldade que os homens destacados para a tarefa o arrastaram dali e levaram-no até Astíages. Ciro fez, então, com que eles ficassem bem na sua frente, porque tinha visto no rosto do seu avô que ele estava furioso diante da sua visão.

Essa passagem não é uma favorita dos comentadores da Ciropédia, mas creio que a maior parte de nós interpreta o fascínio de Ciro pela visão dos cadáveres como "perda de autocontrole", ${ }^{11}$ algo não incomum na adolescência. Afinal, o retrato psicológico da infância e da juventude do futuro rei persa é uma das qualidades comumente apontadas no texto. ${ }^{12}$ Trata-se de um Ciro ainda jovem, cujo comportamento durante a batalha é descrito pelo autor com o símile "um cão filhote de boa raça, mas inexperiente, que se lança sem pensar

\footnotetext{
${ }^{9}$ Xenofonte é aqui bastante aristotélico no que diz respeito à economia de personagens, então o rival dos medos nesse momento já é o príncipe assírio que será, ao longo da narrativa, o grande inimigo a ser derrotado por Ciro, e que ainda jovem havia tentado pilhar o país dos medos, quando ali parara para caçar.

${ }^{10}$ Todos os trechos citados da Ciropédia neste artigo foram traduzidos por mim. Minha tradução completa da obra será publicada pela editora Três Estrelas.

${ }^{11}$ A expressão é de Harman (2009). Cf. Platão, Rep. 439e-440a.

${ }^{12}$ Cf. Ciropédia, I.2.9, em que se diz que na juventude é necessária maior precaução com relação à sophrosyne.
} 
sobre um javali" (I.4.21). ${ }^{13}$ E essa cena é relevante ainda por outro motivo, porque marca não só a primeira batalha de que Ciro participa, mas também um momento - talvez o último? - em que ele ainda não tem consciência de como deve ser visto (uma questão que ele depois mostrará entender ser crucial para o seu sucesso como líder), deixando-se ser observado em comportamento impróprio. A falta de diálogo entre Ciro e o avô, na cena citada acima, é ainda duplicada pela falta de intervenção do narrador, que se abstém de avaliar o comportamento de Ciro; com efeito, Gray (2014, p. 322) observa, comentando a mais famosa passagem da Anábase, que Xenofonte não é "esse tipo de autor"; seu estilo simples é não restritivo e até mesmo democrático, porque respeita o julgamento dos leitores.

Schein (2016) recentemente se queixou que as recepções modernas de Homero tendem a enfatizar as crueldades físicas e psicológicas da guerra, mas raramente capturam o "joy of battle" dos heróis e os frutos econômicos, sociais e quase metafísicos do combate,


Ciro, que por causa dela fica "enlouquecido" ( $\mu$ avó $\mu \varepsilon v o v)$, Xenofonte introduz na narrativa

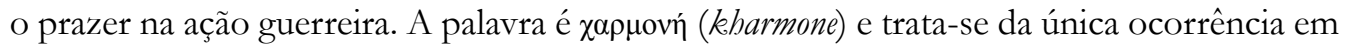

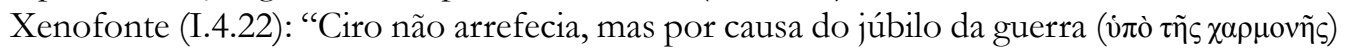
chamava pelo tio e mantinha a perseguição". Embora a guerra seja certamente caracterizada de forma negativa no mais das vezes em Homero, com um grande número de epítetos

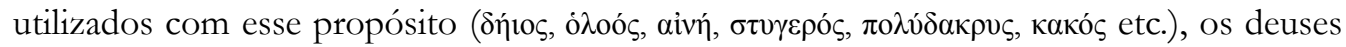
são capazes de fazê-la parecer mais doce do que o regresso ${ }^{14}$ e de instilar nos heróis tamanha

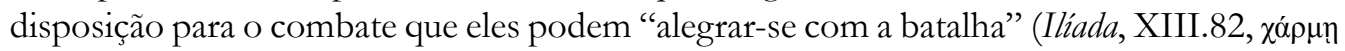

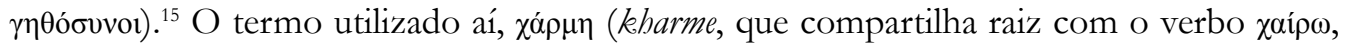
"comprazer-se"), às vezes é traduzido pelos falantes de inglês como o "joy of battle" de que fala Schein (essa é a tradução sugerida também pelo LSJ). O estado mental de Ciro também encontra paralelo na Ilíada: Thalmann (2015, p. 98ss) destaca que há termos em Homero, como $\mu$ śvos (menos) que implicam o reconhecimento de um estado alterado de consciência produzido por atos de violência em batalha, que causa entusiasmo pelo confronto violento.

O júbilo sentido durante a ação em campo de batalha, na Ciropédia, é retratado, porém, claramente de forma negativa: Ciro só se entrega a ele porque é inexperiente e faz parte da sua educação, retratada na obra, o controle também do prazer da violência, da mesma forma em que ele aprende a suportar coisas como a fome, a sede, o frio e o sono. Mas Xenofonte parece sugerir que o prazer da guerra é algo tão natural quanto essas outras coisas, ao menos para Ciro.

O caráter duplo da guerra em Homero é problematizado, ainda, para o receptor externo, que é colocado em alguns momentos, por meio da vivacidade da narrativa ou do olhar dos personagens, na posição de espectador da violência da guerra e de suas consequências. Assim, o combate às vezes é representado como um espetáculo violento, do qual o receptor

\footnotetext{
${ }^{13}$ Cf. I.4.3-4; I.4.8-9.

${ }^{14}$ Ilíada, II.450-55; XI.10-15.

${ }^{15}$ Cf. van Wees (1996, p. 5).
} 
externo pode retirar prazer, ${ }^{16}$ mas ele é, por outro lado, o tempo todo lembrado pelo narrador do sofrimento de pais e de esposas dos heróis mortos. ${ }^{17}$ É importante aqui ressaltar uma diferença: porque Xenofonte está relatando uma guerra, mas ao mesmo tempo fazendo o louvor de Ciro, o combate é retratado de forma positiva; os diversos aspectos de uma guerra são mencionados várias vezes de maneira quase técnica. Pode-se aprender com a Ciropédia, por exemplo, qual a forma mais segura de se montar um acampamento, como posicionar o exército em situações variadas, de que modo racionar o vinho servido às tropas etc. Antes do surgimento de Panteia em cena, que nos interessa particularmente neste artigo, o narrador só havia chamado a atenção uma vez para os sofrimentos da guerra (III.3.67):

As mulheres dos assírios e de seus aliados, vendo que a fuga já se dava até no interior do campo, começaram a gritar e a correr em pânico, tanto as que tinham filhos quanto as mulheres mais jovens, rasgando as roupas e arranhando os rostos, enquanto suplicavam a todos que encontravam para que não fugissem e não as abandonassem, mas que as defendessem, bem como a seus filhos e a si mesmos.

Isso ocorre no interior de uma fortificação que os persas estavam prestes a invadir, mas Ciro, temendo um revés, decide abortar o plano. A meu ver, a cena é descrita apenas com o propósito de enfatizar quão perto o exército medo-persa chegou de aniquilar de vez as forças assírias logo da primeira vez que a enfrentou. Isso dito, o final infeliz de Panteia e de Abradatas no interior de uma obra que narra a ascensão, por meio da guerra, do líder do maior império conhecido até então, ganha outra dimensão.

\section{Panteia e Abradatas encontram Ciro}

Há algumas narrativas encaixadas ao longo da Ciropédia, a de Panteia e Abradatas é a mais longa e desenvolve-se de uma forma inovadora por se apresentar em segmentos intercalados com a narrativa principal, servindo a funções diversas cada vez que mais um pedaço da história do casal de Susa é contada. Para uma breve paráfrase, vou utilizar a divisão proposta por Stadter (1991) de "quatro atos": no primeiro ato (V.1.2-18), Ciro é informado da existência de Panteia por Araspas. Ela é a mulher mais bela da Ásia, tornada cativa de guerra e escolhida pelos soldados como espólio de Ciro (IV.6.12). Impressionado com o relato vivaz que Araspas faz da beleza da mulher, Ciro se recusa a vê-la. Nesse trecho, o que se destaca é o autocontrole de Ciro e seu entendimento de que Eros é irresistível e deve ser evitado. No segundo ato (VI.1.33-44), vemos Araspas, que se julgava superior aos poderes de Eros, sucumbir a ele e ameaçar violentar Panteia, que se queixa a Ciro. Ele envia então Araspas numa missão de espionagem, afastando-o da mulher. Seu comportamento nobre e generoso, ao protegê-la, garante-lhe uma recompensa: um novo e importante aliado de guerra.

\footnotetext{
${ }^{16}$ Cf. Ilíada, XX.23, em que Zeus diz que pretende se comprazer com a visão de deuses e mortais lutando ou VII. 58-61, em que Atena e Apolo se comprazem observando os homens no fim de uma batalha.

${ }^{17}$ Cf. Yamagata (2016) e Myers (2016).
} 
Assim, na sequência, Ciro permite que Panteia mande uma mensagem ao marido, Abradatas de Susa, que deserta para o seu lado (VI.1.46). ${ }^{18}$ Até esse ponto da história, notamos o tema da irresistibilidade de Eros e vemos Ciro receber recompensas por sua sophrosyne.

No terceiro ato, Abradatas recebe a posição mais perigosa na batalha de Thymbrara (VI.3.35-6), no comando de uma ala de carros falcados, e é armado por Panteia e dela se despede (VI.4.2-11). No ato final (VII.1.29-32), Abradatas morre em batalha e, apenas depois da tomada de Sárdis, Ciro é informado de sua morte, encontra Panteia agarrada ao cadáver do marido e parte pouco antes de ela (e seus eunucos) se suicidarem (VII.3.2-16). Nessas duas últimas partes da história, creio que a função da narrativa de Panteia e Abradatas tornase mais complexa e controversa.

Ao descrever o exército de Ciro, Xenofonte chama a atenção para o aspecto das tropas de Ciro por meio de símiles, que são infrequentes na narrativa. Por duas vezes, os soldados são comparados a coreutas: Cambises diz que Ciro verá as tropas como um coro, se seguir

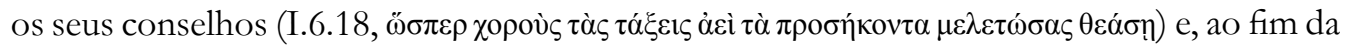
primeira batalha contra os assírios, quando Ciro já ordenara a retirada, o narrador afirma que

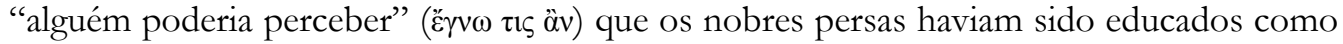
se deve, pois sabiam com mais precisão do que de um coro qual era o posicionamento de

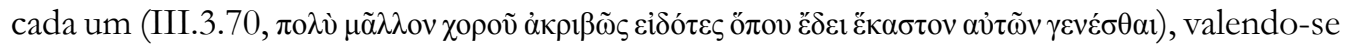
da estratégia do "observador hipotético", já usada em Homero para envolver a audiência.

$\mathrm{Na}$ preparação para a batalha decisiva contra os assírios, Xenofonte descreve brevemente o armamento de Ciro (VII.1.2): "só em um aspecto as armas de Ciro eram diferentes: todas as outras eram pintadas com a cor dourada, apenas as armas de Ciro brilhavam como um espelho". Como bem analisa Gray (2011, p. 133), essa cena serve ao propósito de enfatizar a boa liderança de Ciro: o bom líder não se destaca por ter armas magníficas, mas pelas excelentes condições de seus seguidores, que são iguais às dele. Em vez de uma longa ekphrasis nos moldes épicos, todo o realce que as armas de Ciro recebem são um breve símile. Esse símile é importante dentro do esquema observado por Krischer (1971) sobre a estrutura da aristeia maior de heróis na Ilíada, que é retomado por Howie (1996, p. 199): Xenofonte está aqui emulando Homero por meio da menção ao brilho das armas, que no poeta é sinal do sucesso futuro do herói no combate para o qual se prepara.

Quem, por sua vez, ganha armas magníficas é Abradatas de Susa (VI.4.2-10), ${ }^{19}$ observando-se aqui o padrão homérico em que a cena de armamento de um herói relaciona-

\footnotetext{
${ }^{18}$ Dentre os desertores assírios, como bem notou Gera (1993, p. 234), Abradatas é o único que se dirige a Ciro pelo nome (VI.1.48), apresentando-se como "amigo" (philos), "servo" (therapon) e "aliado" (symmakhos), numa introdução mais dignificante do seu personagem. Por sua vez, Gobrias (IV.6.2) dirige-se a ele como "déspota", como também faz Gadatas (V.3.28), e apresenta-se como "suplicante" (biketes), "escravo" (doulos) e "aliado" (symmakhos).

${ }^{19}$ Gray (2011, p. 136): "It begins with the general arming of the infantry and cavalry (Cyr. 6.4.1) and is followed by the specific arming scene of the hero Abradatas (6.4.2-9), who is one of those who joined Cyrus in the course of his crusade. Homer gives us a similar structural combination when he combines a preceding description of the arming of the masses with the individual arming of Achilles at the end of Iliad 19, which is the greatest of the arming scenes".
} 
se ao seu status e importância na narrativa. Abradatas é transformado em espetáculo pela esposa (VI.4.2), quando, pouco antes de a batalha começar, às vistas de todos, ela o veste com uma longa túnica púrpura drapeada até os pés e uma pluma para o elmo da cor do jacinto, bem como com armas de ouro, feitas a partir das suas próprias joias. O resultado é que "se mesmo antes Abradatas era digno de ser notado, vestido com essas armas, ele então pareceu o homem mais belo de todos e o de espírito mais livre, pois essa era a sua natureza" (VI.4.4). A importância dada ao aspecto físico de Panteia e de Abradatas não é gratuita, mas, aqui, serve a um retrato heroico dos personagens. Afinal, "em Homero, a distinção visível do herói é uma marca essencial de ser um herói (...) na teichoscopia, os príncipes da força grega são imediatamente vistos como figuras excepcionais" (Goldhill, 2010, p. 167), altura e beleza sendo aspectos relevantes. ${ }^{20}$

Diversos pontos de contato com a passagem do canto VI da Ilíada em que Heitor e Andrômaca se despedem um do outro podem ser apontados, uma cena com a qual a associação é quase que imediata. Afinal, "o demorado olhar de Andrômaca, olhando para trás enquanto obedientemente deixa as muralhas, é o início da história de todos os olhares femininos a heróis que estão partindo" (Lovatt, 2013, p. 226). Eu mencionarei apenas as principais, uma vez que essa passagem já foi analisada por diversos comentadores, ${ }^{21}$ ressaltando principalmente as diferenças entre Homero e Xenofonte. Observo que Tsagalis (2002) demonstrou que a mesma passagem iliádica do canto VI serviu de inspiração para uma cena da Anábase em que Clearco discursa aos seus soldados (I.3), de modo que podemos argumentar que Xenofonte percebia na passagem um momento de especial importância no poema.

Após vestir Abradatas com as armas, Panteia pede que as pessoas ao redor se retirem. Ela toma a iniciativa de falar, como Andrômaca; ambas têm lágrimas nos olhos. Porém, se a heroína da Iliada quer desencorajar Heitor a lutar, pedindo que se compadeça do filho e da esposa, Panteia, ao contrário, pede que Abradatas lute. Ela começa seu discurso lembrando ao marido o quanto ela o ama, mas, em seguida, declara: "eu prefiro muito mais vir a estar na companhia de um homem que agiu de forma nobre, deitada ao seu lado na terra, do que viver desonrada ao lado de um homem desonrado". Andrômaca também deseja juntar-se a Heitor se ele morrer na batalha (VI.410-412: "para mim seria vantagem, após te perder, afundar na terra"), ${ }^{22}$ mas porque então ela só teria tristezas na vida.

Panteia, na sequência, lembra ao marido que chegou a Ciro como cativa e espólio de guerra; trata-se de outro tema épico, que aparece também na cena que discutimos em fala de Heitor, que imagina Andrômaca um dia sendo escravizada, chorando, recebendo ordens, carregando água... Panteia, porém, considera que foi tratada como se fosse "a esposa do próprio irmão" de Ciro. Se Andrômaca perdeu toda a sua família por causa de Aquiles e

\footnotetext{
${ }^{20}$ Veja-se como os persas (incluindo Ciro) passarão a usar truques para parecerem mais altos, uma vez estabelecida Babilônia como a capital do império. Cf. VIII.1.41; VIII.2.14.

${ }^{21}$ Cf. Gera (1993, p. 235ss); Mueller-Goldingen (1995, p. 207ss), Gray (2011, p. 132ss), Tatum (1989, p. 163ss).

${ }^{22}$ As traduções da Ilíada citadas neste artigo são de Werner (2018).
} 
não tem mais ninguém, para a tola Panteia, Ciro não é o homem que a fez prisioneira, mas se tornou sua própria família.

Ela diz a Abradatas que eles têm uma dívida de gratidão com Ciro também porque havia lhe prometido que, se ele a deixasse enviar alguém até o marido, este viria a ser um homem muito melhor e mais confiável que Araspas. Já se observou que não é Abradatas que se preocupa, como Heitor, com a opinião pública (VI.441-442), mas a mulher, Panteia, e que ele apenas quer se mostrar digno da esposa e da amizade de Ciro. No entanto, a fala de Panteia aqui, de fato, aproxima a motivação de lutar daquela de um herói iliádico: a busca do kleos na Ilíada é apenas parte de um contexto mais amplo em que o herói se preocupa com a sua reputação, ${ }^{23}$ sendo outros dois motivos importantes a obrigação de proteger os companheiros e a performance de uma masculinidade idealizada ou, nas palavras de van Wees (1996, p. 21), "o medo da crítica e do ridículo que acompanhariam a incapacidade de lutar pelos amigos". Ao enfatizar a dívida que eles têm com Ciro, Panteia estabelece a motivação da luta como um dever moral e social; com efeito, diversos outros soldados lutavam ao lado de Ciro por considerar que lhe deviam um favor. ${ }^{24}$ Observo também que, no período de preparação para o combate, ele incentivava a competição entre os soldados, acreditando que seu desempenho seria superior caso pudessem parecer a ele, Ciro, melhores do que os companheiros (VI.2.4).

Heitor faz uma prece diante de Andrômaca, invocando na oração a mesma ética que fará com que ele, Andrômaca e Astíanax morram (VI.476-481), quando deseja que seu filho seja melhor do que ele em guerra e traga os espólios ensanguentados do inimigo para casa:
"Zeus e outros deuses, concedei que também esse meu filho se torne como eu, proeminente entre os troianos e bravo igual na força e, poderoso, reja Ílion.
Diga-se um dia 'esse é muito melhor que o pai', vindo ele de uma batalha; traga armas sangrentas, após matar um varão hostil, e se alegre a mãe".

Abradatas responde a Panteia, então, igualmente com uma prece: "Zeus magnânimo, permita que eu me mostre um homem digno de Panteia e um amigo digno de Ciro, que nos tratou de forma honrada". Como observa Tatum (1993, p. 180), ocorre uma "significativa contração da imaginação heroica" na adaptação de Xenofonte, mas é importante ressaltar que o código de Abradatas, tornado herói pela forma como é representado, é baseado na demonstração de virtude e amizade para Ciro, que substitui toda a comunidade troiana na imaginação desse homem prestes a entrar em batalha. A cena, além disso, prenuncia a morte de Abradatas nessa mesma batalha - não é sem propósito que, a despeito da riqueza das armas que ganha da esposa, o narrador não menciona o seu brilho (Howie, 1996, p. 207). Sem consolar a esposa, como faz Heitor antes de partir, ele sobe no carro, que Panteia beija e acompanha até que o marido a mande embora.

\footnotetext{
${ }^{23}$ Sobre as motivações do herói homérico para lutar, cf. Van Wees, (1996, p.13ss).

${ }^{24}$ Cf. IV.2.10. Obtenção de riquezas, glória e patriotismo são outros motivadores: I.5.9; I.5.12.
} 
Com relação ao vocabulário utilizado na cena de despedida, eu encontrei apenas um

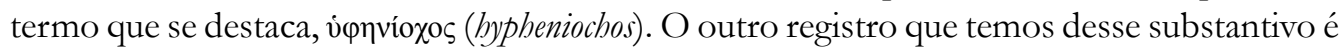
na Ilíada (VI.19) e mesmo Xenofonte, com exceção das passagens em que descreve a atuação de Abradatas na batalha (VI.4.4; VI.4.10; VII.1.15), usa por diversas vezes na Ciropédia o

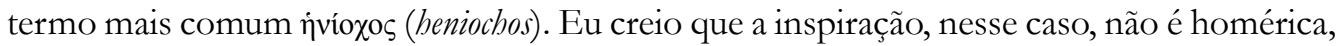
porque a palavra ocorre apenas uma vez na Ilíada - Aristarco teria notado que o prefixo é desnecessário (Kirk, 1990, p. 157) - e porque o próprio contexto em que o termo está sendo utilizado o justifica, já que permite indicar Abradatas como condutor principal do carro de guerra falcado, auxiliado por um auriga, o "subcondutor", rebaixado com intenção de enfatizar a importância da atuação do herói de Susa.

\title{
As mortes de Panteia e de Abradatas
}

A guerra começa, na Ciropédia, porque os medos precisam se defender da agressão assíria (I.5.2), e, quando Ciro tem a possibilidade de expandir seu poder, nós somos levados a torcer por ele porque o novo rei assírio é um homem violento e cruel e porque achamos justo que ele supere seu tio e rei dos medos, Ciaxares, retratado como um líder desprovido de qualidades. Quando começa a batalha de Thymbrara, o leitor não só sabe, mas quer que o espetacular exército de Ciro saia vitorioso, destrinchando as carreiras inimigas com seus carros falcados.

Antes de a batalha ter início, Ciro havia instruído Abradatas (VII.1.17) a não partir para o ataque antes que ele visse os egípcios começando a debandar, uma instrução que ele não segue, o que acaba provocando sua morte. Todos os homens da sua ala, com exceção de ele próprio e de seus amigos, fogem antes de encarar os egípcios. Sua morte é a única descrita por Xenofonte. O leitor vai acompanhando o olhar do narrador pelo campo de batalha desde o ponto mais distante, quando ele diz que o exército de Ciro é rodeado pelo dos inimigos como se houvesse uma letra $\Pi$ (pi maiúsculo) dentro de outra, e passa pelas diversas alas dos exércitos, fazendo apenas uma pausa para apontar a morte de Abradatas e de

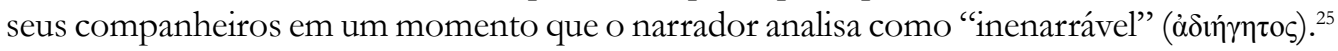
Eis o momento em que Abradatas perde a vida (VII.1.29-32):

\begin{abstract}
No local onde Abradatas e seus seguidores atacaram, porque os egípcios não podiam bater em retirada em razão do fato de que havia homens lutando firmes de ambos os seus lados, os que estavam de pé eram derrubados com golpes e pela força dos cavalos, enquanto os que caíam eram destroçados, eles próprios e suas armas, pelos cavalos e pelas rodas. O que quer que fosse apanhado pelas foices era trinchado com toda a violência, fossem armas, fossem corpos.
\end{abstract}

\footnotetext{
${ }^{25}$ A impossibilidade de escrever sobre a guerra é um aspecto compartilhado por narrativas de guerra: "The reasons that make war's representation imperative are as multitudinous as those which make it impossible: to impose discursive order on the chaos of conflict and so to render it more comprehensible" (Mcloughlin, 2011, p. 7).
} 
Nessa confusão indescritível, as rodas saltavam ao passar por amontoados de toda espécie e, por isso, Abradatas e outros que haviam entrado em combate com ele foram ao chão e, ali, esses homens que se mostraram tão corajosos foram massacrados e mortos.

Muito diferentemente de um herói homérico, para quem uma das principais motivações para lutar é a necessidade de vingar um companheiro, o fato de que a história de Panteia e Abradatas vem entremeada ao longo da narrativa permite que Ciro acolha como aliados seus inimigos egípcios, responsáveis diretos pela morte de Abradatas, logo que se sai vencedor na batalha, sem saber que o homem de Susa havia sido morto por eles. Para Howie (1996, p. 211), a representação de Ciro pode ser entendida por contraposição à Ilíada, em que os deuses intervêm nos combates para impor compaixão ao vencido e limites ao aristeus, porque Ciro espontaneamente demonstra preocupação com a vida humana. Essa leitura, porém, a meu ver deve vir coordenada com aquela que entende a atitude de Ciro como adequada ao seu código de conduta, segundo o qual se troca reciprocidade entre amigos ou submissão violenta por obediência voluntária, e cultivam-se as relações que sejam mais úteis. Como nota Buxton (2017, p. 334), ainda que Xenofonte acate a maioria das características que o senso comum grego entendia como desejáveis em um líder, essa obediência não imposta é "decididamente uma contribuição nova" da concepção de Xenofonte do que constitui um bom líder.

Para Stadter (1991), a novella de Panteia e Abradatas tem a função de desenvolver de forma dramática e persuasiva o argumento de que Ciro tem virtudes morais por detrás das suas vitórias militares (o autoconhecimento e o autocontrole), mas essa leitura tem o problema de que ela torna os episódios finais, que envolvem a morte de Panteia e Abradatas, irrelevantes. Mesmo problema apresenta a interpretação de Mueller-Goldingen (1995, p. 210-11), que sugere que a história tem função dupla: por um lado, estabelecer Panteia como paradigma de mulher leal, por outro, fazer o louvor de Ciro em contraposição a Araspas (a não ser que consideremos que a mulher ideal deve se suicidar após a morte do marido). $\mathrm{Na}$ leitura de Tatum (1989, p. 182ss) de Ciro como um líder maquiavélico, que ascende ao poder pela manipulação de todos ao seu redor tendo em vista a preservação dos seus próprios interesses, a história pode ser lida politicamente, com o entendimento de Ciro de que o poder político é vulnerável a Eros. Declarando que os episódios que envolvem Panteia e Abradatas são a única parte da Ciropédia de grande interesse literário, Tatum defende que o sentido mais relevante de suas mortes é o de que Ciro é responsável por elas (ibid., p. 188): "um príncipe deve ser capaz de encontrar boas pessoas dispostas a morrer a seu serviço". Nessa leitura, porém, a relação construída com Homero importa pouco, sendo irrelevante para o entendimento da obra. Por sua vez, outros comentadores consideram o prazer estético da história de Panteia e de Abradatas como causa da sua inserção na Ciropédia, ${ }^{26}$ as alusões literárias sendo elementos que operam na construção desse prazer. Esses autores

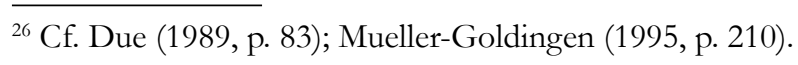


nem sempre consideram, porém, o contexto mais imediato da narrativa, em que os episódios devem ter alguma função.

A morte de Abradatas só é lamentada após o fim da batalha, a tomada de Sárdis e o encontro entre Creso e Ciro. Ao perguntar sobre Abradatas e ser informado da sua morte, Ciro esmurra a própria coxa, demonstrando sua dor por meio de um gesto retratado na Ilíada e na Odisseia ${ }^{27}$ e que não se repete em nenhuma outra passagem em Xenofonte. Ciro se dirige até o local onde a mulher estava com o corpo, logo que é informado da morte (VII.3.8):

Depois de ver a mulher sentada no chão e o morto que ali jazia, começou a chorar pelo triste acontecimento e disse, "ai, bela e fiel alma, então você se foi e nos deixou?". Ele segurou a mão direita de Abradatas e ela se soltou do corpo, pois havia sido decepada por um golpe de espada dos egípcios.

Panteia beija a mão, coloca-a de volta no lugar e dirige-se a Ciro, afirmando que todo o corpo estava naquelas condições e perguntando que necessidade ele tinha de vê-lo


$\mu \omega ́ \rho \alpha)$ e declara que os responsáveis pela morte de Abradatas são ela, que o havia encorajado a lutar "para ser um amigo digno", e o próprio Ciro.

O tema do cadáver mutilado ${ }^{28}$ é de grande relevância na Ilíada, mas está inserido nesse momento na Ciropédia em contexto bastante diferente daquele em que aparece no poema. Qual o ponto aqui, além do acentuado tom patético que a visão dos membros decepados traz ao texto? Em primeiro lugar, lembremos que uma das formas da aikia, da mutilação do cadáver na Ilíada, é o desmembramento - a perda da integridade impede que o corpo do herói mantenha sua beleza gloriosa: "o corpo é reduzido ao estado de coisa ao mesmo tempo em que é desfigurado" (Vernant, 1979, p. 27). Embora o narrador diga que a mão de Abradatas havia sido decepada por um golpe de espada dos inimigos, talvez seja possível também supor (a partir da passagem citada mais acima) que o estado do seu corpo seja parcialmente resultado da ação dos próprios carros falcados que estavam sob seu comando. Assim, o cadáver pode não ter sido mutilado deliberadamente pelos egípcios, mas pelo descontrole de um dos formidáveis artefatos de guerra inventados por Ciro e do qual acaba por ser vítima um de seus melhores homens. Trata-se de um invento eficaz, mas o efeito das lâminas atreladas às rodas de um carro no corpo do nobre Abradatas chega ao limite máximo da violência contra o cadáver de um guerreiro, retratada na Ilíada como algo incivilizado e selvagem.

Lembremos ainda que, ao fim do canto XXII (v. 460-74), Andrômaca observa das muralhas o corpo de seu esposo sendo arrastado por cavalos, momento no qual ela desmaia. Como analisa Segal (1971, p. 44)

${ }^{27}$ Ilíada, XII.162; XV.113; Odisseia, XIII.198.

${ }^{28}$ Agradeço a Leonard Muellner por ter chamado minha atenção para a importância de analisar o estado do corpo de Abradatas a partir da forma como o tema da mutilação do cadáver é apresentado na Ilíada. 
A visão a partir da muralha é a violação mais dolorosa possível do amor e do respeito com os quais uma esposa trataria os restos do marido (...) Homero faz de Andrômaca nesse ponto aquela que suporta a mais extrema das crueldades da guerra.

Embora me pareça haver aí novamente um claro paralelo entre os dois casais, a mutilação do corpo de Heitor não se concretiza como se concretiza a de Abradatas para Panteia. Assim, ainda que Ciro deseje honrar a morte "gloriosa" de Abradatas, as peças já não parecem se encaixar muito bem. Para demonstrar sua estima, antes de ir ao encontro da viúva, ele havia pedido que dois de seus homens mais próximos, Gobrias e Gadatas, levassem "ornamentos belos que pudessem encontrar para o homem querido e valoroso que havia falecido" (VII.3.7) e mandado também que bois, cavalos e ovelhas fossem levados para o local, para que ali se realizasse um sacrifício. A visão do corpo mutilado de Abradatas, porém, causa desconforto e atenua a impressão de uma morte heroica.

O fato é que a violência que tanto fascinou o jovem Ciro é justificada, glorificada e transformada em espetáculo ao longo da Ciropédia, sendo um dos motivos o fato de que Xenofonte escolheu escrever uma narrativa fictícia, e não um tratado político, sobre o líder ideal. Nesse contexto, ao leitor é permitido ver o corpo mutilado de Abradatas duas vezes; uma, no próprio campo de batalha, onde ele sofre uma morte nobre e digna, defendendo Ciro, inserido numa tradição de ação heroica, que começa já quando somos convidados a vê-lo em todo o esplendor das suas armas de ouro; a segunda, quando podemos ter uma dimensão mais completa dessa morte, sob o olhar de Panteia. Panteia e Abradatas servem a propósitos vários na narrativa, mas suas mortes nos fazem refletir que, como o jovem Ciro, também o leitor precisa ser arrancado em algum momento dessa situação de fascínio e ser lembrado dos aspectos negativos da guerra.

Baragwanath (2017) argumentou recentemente que o arrependimento de Panteia atinge o cerne de todo o sistema de poder de Ciro, que é baseado em uma relação de philia utilitária. Sua morte expõe de forma problemática o código de liderança de Ciro, cujo fundamento se encontra na total devoção a ele. Que esse questionamento seja feito em uma narrativa encaixada de acentuado teor homérico e nas palavras da própria heroína não é algo fortuito. Como observa Schein (2016, p.151), na Ilíada, instituições e valores tradicionais são afirmados e transmitidos, ${ }^{29}$ mas eles eram notavelmente questionados ou desafiados na linguagem figurada e nos discursos dos personagens; para o crítico, talvez as recepções de Homero muitas vezes falhem em representar tanto os aspectos positivos quanto os negativos da guerra porque essa capacidade seria uma característica específica da poesia épica oral tradicional.

\footnotetext{
${ }^{29}$ Cf. o interessante artigo de Thalmann (2015), que analisa como a Ilíada problematiza a violência ao representá-la. $\mathrm{O}$ autor demonstra como o poema mostra um mundo condicionado pela violência e quais são as implicações disso para a sociedade, bem como aponta possibilidades de controlá-la.
} 
Essa é uma falha que vejo como ausente na recepção da Ilíada na Ciropédia. Assim como Heitor (e Clearco) ${ }^{30}$ caem vítimas dos códigos heroicos que orientam suas vidas, também Abradatas e Panteia acabam por se tornar vítimas do seu desejo de agradar Ciro. Ao leitor da Ciropédia, uma obra tantas vezes injustamente considerada plana e enfadonha, resta perceber que, nessa infeliz história de amor, os tons homéricos surgem em uma estratégia, emprestada do poeta, de trazer na obra que glorifica um líder e seu código de conduta também um questionamento desse mesmo líder e da forma pela qual ele conquista seu império.

\section{REFERÊNCIAS}

BARAGWANATH, Emily. The character and functions of speeches in Xenophon. In: FLOWER, Michael (Ed.). Cambridge companion to Xenophon. Cambridge/New York: Cambridge University Press, 2017, p. 279-300.

BUXTON, Richard Fernando. Xenophon on leadership: commanders as friends. In: FLOWER, Michael (Ed.). Cambridge companion to Xenophon. Cambridge/New York: Cambridge University Press, 2017, p. 323-37.

DANZIG, Gabriel. The best of the Achaemenids: benevolence, self-interest and the 'ironic' reading of Cyropaedia. In: HOBDEN, Fiona; TUPLIN, Christopher (Ed.). Xenophon. Ethical principles and historical enquiry. Leiden: Brill, 2012, p. 499-539.

DUE, Bodil. The Cyropaedia. Xenophon's aims and methods. Aarhus: Aarhus University Press, 1989.

GERA, Deborah. Xenophon's Cyropaedia. Style, genre, and literary tecbnique. New York: Oxford University Press, 1993.

GOLDHILL, Simon. The seductions of the gaze: Socrates and his girlfriends. In: GRAY, Vivienne (Ed.). Xenophon. Oxford readings in Classical Studies. New York: Oxford University Press, 2010, p. 167-93.

GRAY, Vivienne. Xenophon's mirror of princes. Reading the reflections. Oxford/New York: Oxford University Press, 2011.

GRAY, Vivienne. Le style simple de Xénophon: du rabaissement de la grandeur. In: PONTIER, Pierre (Ed.). Xénophon et la rhétorique. Paris: Presses Universitaires de ParisSorbonne, 2014, p. 319-37.

HARMAN, Rosie. Viewing, power and interpretation in Xenophon's Cyropaedia. In: PIGON, Jakub (Ed.). The children of Herodotus. Greek and Roman bistoriography and related genres. Newcastle: Cambridge Scholars Publishing, 2009, p. 69-91.

HOMERO. Ilíada. Tradução de Christian Werner. São Paulo: Ubu, 2018.

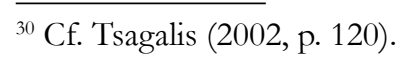


HOWIE, J. Gordon. The major aristeia in Homer and Xenophon. Papers of the Leeds International Latin Seminar, v. 9, p. 197-217, 1996.

HOWLAND, Jacob. Xenophon's philosophical odyssey: on the Anabasis and Plato's Republic. American Political Science Review, v. 94, n. 4, p. 875-89, 2000.

KIRK, Geoffrey Stephen (Org.). The Iliad. A commentary. Cambridge: Cambridge University Press, 1990. v. 2, books 5-8.

KRISCHER, Tilman. Formale Konventionen der homerischen Epik. München: C. H. Beck, 1971.

LOSSAU, Manfred. Xenophons Odyssee. Antike und Abendland, n. 36, p. 47-52, 1990.

LOVAT'T, Helen. The epic gaze. Vision, gender and narrative in ancient epic. Cambridge/New York: Cambridge University Press, 2013.

MARINCOLA, John. Odysseus and the historians. Syllecta Classica, v. 18, p. 1-79, 2007.

MARINCOLA, John. Xenophons' Anabasis and Hellenica. In: FLOWER, Michael (Ed.). Cambridge companion to Xenophon. Cambridge/New York: Cambridge University Press, 2017, p. 103-18.

McLOUGHLIN, Kate. Authoring war. The literary representation of war from Iliad to Iraq. Cambridge/New York: Cambridge University Press, 2011.

MUELLER-GOLDINGEN, Christian. Untersuchungen zu Xenophons Kyrupädie, Stuttgart: Teubner, 1995.

MYERS, Tobias. What if we had a war and everybody came? War as spectacle and the duel of Iliad 3. In: BAKOGIANNI, Anastasia; HOPE, Valerie (Ed.). War as spectacle. Ancient and modern perspectives on the display of armed conflict. London/New York: 2016, p. 25-42.

NÜNLIST, René. Poetics and literary criticism in the framework of ancient Greek scholarship. In: MONTANARI, Franco; MATTHAIOS, Stefanos; RENGAKOS, Antonios (Ed.). Brill's companion to ancient Greek scholarship. Leiden/Boston: Brill, 2014, p. 706-55.

SCHEIN, Seth. "War - what is it good for?" in Homer's Iliad and four receptions. In:

Homeric epic and its receptions. Interpretative essays. Oxford: Oxford University Press, 2016, p. 149-70.

SEGAL, Charles. The theme of the mutilation of the corpse in the Iliad. Leiden: Brill, 1971.

STADTER, Philip. The fictional narrative in the Cyropaedia. American Journal of Philology, v. 112, p. 461-91, 1991.

TATUM, James. Xenophon's imperial fiction. On the Education of Cyrus. New Jersey: Princeton University Press, 1989.

THALMANN, William G. 'Anger sweeter than dripping honey': violence as a problem in the Iliad. Ramus, v. 44, n. 1-2, p. 95-114, 2015. 
TSAGALIS, Christos. Xenophon homericus: an unnoticed loan from the Iliad in Xenophon's Anabasis. Classica et Mediaevalia, v. 53, p. 101-21, 2002.

TUPLIN, Christopher. Heroes in Xenophon's Anabasis. In: BARZANÒ, Alberto; GATTINONI, Franca; BEARZOT, Cinzia (Ed.). Modelli eroici dall' antichità alla cultura europea. Roma: L'Erma di Bretschneider, 2003, p. 115-56.

VAN WEES, Hans. Heroes, knights and nutters. Warrior mentality in Homer. In: LLOYD, Alan (Ed.). Battle in Antiquity. Swansea: Classical Press of Wales, 1996, p. 1-86.

VERNANT, Jean-Pierre. A bela morte e o cadáver ultrajado. Trad. Elisa A. Kossovitch e João A. Hansen. Discurso, n. 9, p. 31-62, 1979.

YAMAGATA, Naoko. Use of Homeric references in Plato and Xenophon. The Classical Quarterly, v. 62, n. 1, p. 130-44, 2012.

YAMAGATA, Naoko. From our own correspondent. Authorial Commentary on the 'Spectacles of War' in Homer and in the Tale of the Heike. In: BAKOGIANNI, Anastasia; HOPE, Valerie (Ed.). War as spectacle. Ancient and modern perspectives on the display of armed confict. London/New York: 2016, p. 43-56. 